This item was submitted to Loughborough's Research Repository by the author.

Items in Figshare are protected by copyright, with all rights reserved, unless otherwise indicated.

\title{
Enlightenment geography in the study: A.F. Busching, J.D. Michaelis and the place of geographical knowledge in the Royal Danish Expedition to Arabia, 1761-1767
}

\section{PLEASE CITE THE PUBLISHED VERSION}

https://doi.org/10.1016/j.jhg.2015.09.002

\section{PUBLISHER}

(C) Elsevier

\section{VERSION}

AM (Accepted Manuscript)

\section{PUBLISHER STATEMENT}

This work is made available according to the conditions of the Creative Commons Attribution-NonCommercialNoDerivatives 4.0 International (CC BY-NC-ND 4.0) licence. Full details of this licence are available at: https://creativecommons.org/licenses/by-nc-nd/4.0/

\section{LICENCE}

CC BY-NC-ND 4.0

\section{REPOSITORY RECORD}

Bond, Dean W.. 2019. "Enlightenment Geography in the Study: A.F. Busching, J.D. Michaelis and the Place of Geographical Knowledge in the Royal Danish Expedition to Arabia, 1761-1767". figshare.

https://hdl.handle.net/2134/32023. 
In January 1768, the geographer Anton Friedrich Büsching wrote to his friend Johann David Michaelis to update him on his work concerning the geography of Arabia:

As an indemnity I'm sending you three new geographical pages belonging to the continuation of the description of Arabia. To my displeasure, however, the complete description of Mount Sinai and the stated rock that Moses was supposed to have smashed is not included in these pages....When the page containing this material is complete, I shall send it you by post. The [description of] Sinai has cost me much effort and time, and therefore I view my treatment of it as significant and your evaluation of it as valuable. ${ }^{1}$

Büsching viewed Michaelis's evaluation as valuable because Michaelis, a scholar of Oriental languages and biblical philology, was interested in and knowledgeable about the geography of the Bible. Indeed, geography was one of the many subjects - including the 'natural sciences' (Naturwissenschaften) and history - that Michaelis saw as crucial aids to understanding the Bible's linguistic and cultural context. ${ }^{2}$ His belief in geography's utility led him to edit dual language editions of geographical works by the ancient Arab geographer Ismael Abulfeda, and helped spur him to organize the Royal Danish Expedition to Arabia (1761-1767), which sent a 'company of learned men' to investigate the geography and natural history of Arabia felix (Yemen) and saw only the expedition's 'mathematician', Carsten Niebuhr, return. ${ }^{3}$ Michaelis's interest in geography, moreover, motivated him to correspond with Büsching about the Arabian expedition and the fifth volume of Büsching's magnum opus, the Neue Erdbeschreibung (New Earth Description, 11 volumes, Hamburg, 1754-1792), an account of Asia which first appeared in the year following the expedition's close. ${ }^{4}$ 
Büsching's 'geography of Asia' and Michaelis's Arabian expedition were part of an interwoven history. This history, however, has received little attention from geographers or historians. Geographers have suggested that Büsching helped Michaelis formulate questions for the Arabian expedition but have said little about the nature of Büsching's involvement or his relationship to Michaelis. ${ }^{5}$ Michaelis never directly credited Büsching with helping him formulate questions, but rather only mentioned that he received help from his 'learned friends' in Göttingen and elsewhere in the German territories and Europe. ${ }^{6}$ Büsching had little direct influence on the expedition's planning and undertaking, and my aim is not to argue that he did. Rather, I suggest that the story of the correspondence between Büsching and Michaelis, and their evaluations of the expedition, has important implications for how we understand the study-field distinction and Enlightenment 'cultures of exploration'.7

This is particularly important because although historians have done much to illuminate the nature and importance of Niebuhr's geographical fieldwork, they have overlooked the ways Michaelis's and Büsching's armchair geography, a product of the scholar in the study (Stubengelehrter), figured in the expedition's history. ${ }^{8}$ Consideration of this form of geography is necessary because it complicates understandings of the relationship between the study, the field and learned authority in the expedition. I argue that armchair geography is important more broadly because it sheds light on the production and moral economy of knowledge at work in 'German Enlightenment geography', or what I call Aufklärungsgeographie. ${ }^{9}$

In discussing the interwoven and messy histories of Büsching and Michaelis's projects, this paper draws on recent work concerning Enlightenment geography and the 
geography of early modern science. Enlightenment geography was both a 'discipline', namely 'what contemporaries took geography to be', and a 'discourse', namely practices such as 'observing, mapping, collecting, comparing, writing, sketching, classifying, reading, and so on ... through which people came to know the world'. ${ }^{10}$ Enlightenment geography was, like Enlightenment science more broadly, shaped by the geographies of Enlightenment, namely places such as studies, coffee houses, libraries, lecture halls and churches 'in which enlightenment, as a process, a set of ideas, was produced, debated, and consumed'. ${ }^{11}$ The geography of Enlightenment geography, moreover, was linked with a moral economy of knowledge, namely a web of 'morally textured relations' between scholars and scientists that involved 'notions like authority and trust and the socially situated norms which identify who is to be trusted, and at what price trust is to be withheld'. ${ }^{12}$ As such, questions about the trustworthiness, authority and credibility of geography's practitioners were bound up with questions about where knowledge was made and who made it. ${ }^{13}$

This paper discusses how concerns with the geography and moral economy of scientific knowledge figured in Büsching and Michaelis's geographical practice at home in the context of the Arabian expedition. The paper is in four parts. The first discusses recent arguments in the literature concerning learned authority's place in the Arabian expedition. The second discusses the origins of Büsching's Neue Erdbeschreibung project and suggests that his effort to establish a new methodological foundation for geography was inseparable from concerns with learned authority and its geography. It also outlines how concerns with the geography of learned authority were manifest in Büsching and Michaelis's correspondence concerning the Danish expedition and in the first edition of Büsching's 
geography of Asia. It shows that claims to authority, and recognition of the limits to authority, were closely linked and shaped Büsching and Michaelis's study-based efforts to understand 'the East' and to direct the travellers sent to Arabia. The third part examines how Büsching integrated Niebuhr's reports in subsequent editions of his geography of Asia, and how he and Michaelis evaluated Niebuhr's printed geographical works in the learned journals they edited. In so doing it shows they believed Niebuhr's work bolstered their claims to produce credible knowledge in the study. It demonstrates that Büsching and Michaelis sought to integrate knowledge of the study and the field in ways that allowed them to produce more accurate knowledge of Asia's historical and contemporary geography, and to legitimate the credibility and necessity - rather than the superiority - of textual critique in the study. More broadly, I argue that understanding the relations between the historical constitution of the study, the production of geographical knowledge through correspondence, and the movement of geographical knowledge between different print forms is crucial for understanding the making of Enlightenment geography and its moral economy. ${ }^{14}$

\section{THE ARABIAN EXPEDITION AND THE GEOGRAPHY OF LEARNED AUTHORITY}

Questions about learned authority and the relations between the study and the field were central to Michaelis's efforts to plan and evaluate the Danish expedition to Arabia. The expedition's aim was to gather material concerning 'geography, the ancients, and the natural history of the East' that would help resolve questions about the Exodus story and Mosaic law. Although initially proposed by Michaelis in 1753, the expedition only became possible three years later when he secured the Danish crown's support. ${ }^{15}$ Michaelis spent 
the next few years planning the expedition with the help of the German-born Danish Foreign Minister, Johann Hartwig Ernst von Bernstorff. Michaelis and Bernstorff selected a 'company of learned men' to undertake the mission. They included a Danish philologist (Frederik Christian von Haven), a Swedish naturalist (Petrus Forsskål), a German 'mathematician' and surveyor (Carsten Niebuhr), a German artist (Georg Bauernfeind), and a Danish medical doctor (Christian Carl Cramer). Drawing on replies from scholars in Göttingen and other cities across Europe, along with the input of scholars the Danish crown had appointed to review his work, Michaelis put together a set of questions and instructions to guide the travellers that were eventually published as Fragen an eine Gesellschaft gelehrter Männer, die auf Befehl ihro Majestät des Königes von Dännemark nach Arabien reisen (Questions to a Company of Learned Men Travelling to Arabia at the Behest of His Majesty the King of Denmark, Frankfurt a.M., 1762). He believed that well-prepared travellers armed with these questions could produce new insights into biblical philology and other fields of knowledge. Michaelis's vision came to fruition in January 1761 when the five men left Copenhagen for Arabia felix. ${ }^{16}$

The expedition did not go as planned. Although the travellers had departed with 'a full set of questions' from the Paris-based Academie Royale des Inscriptions et des Belles Lettres, a 'lengthy paper' from the Danish natural scientist Christian Gottlieb Kratzenstein that dealt with 'botany, zoology, especially marine biology, and the navigational sciences', and copies of the questions that scholars from across Europe had sent to Michaelis in the expedition's preparation phase, they had received only 'two very brief questions' from Michaelis before they left. After they had departed, Bernstorff sent them the remainder of Michaelis's questions in manuscript form, which they had a complete set of by 1763.17 
However, shortly after the travellers arrived in Yemen in late 1762, von Haven and Forsskål died of malaria. Niebuhr, Cramer and Bauernfeind also became sick and decided to leave the Arabian peninsula for Bombay in August 1763. En route to Bombay, Bauernfeind and the party's servant Berggren succumbed to malaria, whilst Cramer passed away after he and Niebuhr reached India. Only Niebuhr survived the journey.

In Bombay, Niebuhr finally received the printed edition of Michaelis's Fragen. He stayed in India until 1765, when he began an overland trek back to Copenhagen through the Middle East and Europe. On this trek Niebuhr accomplished much of his important work in geography and ancient studies. ${ }^{18}$ He returned to Copenhagen in November 1767, and in the following years wrote his Beschreibung von Arabien (Description of Arabia, Copenhagen, 1772) and the Reisebeschreibung von Arabien (Travel Account of Arabia, 2 volumes, Copenhagen, 1774 and 1778). Niebuhr also edited and published the botanical and zoological notes of his deceased colleague Forsskål. ${ }^{19}$ Niebuhr's efforts to edit his deceased colleague's work and his own accounts show that despite setbacks in the field and organizational problems, the expedition gathered significant data concerning the botany, natural history and geography of a region Europeans knew comparatively little about. ${ }^{20}$

Studies of the expedition have foregrounded the ways learned authority and the study-field relationship mattered to its history. Carey has addressed these matters in a recent paper on the place of Michaelis's Fragen in the history of travel, where he shows that Michaelis's 'Arabian voyage synthesised a history of prior experience in directing travel to useful ends'. Past expeditions had drawn up questions to direct 'action at a distance', yet Carey argues that Michaelis's efforts to do so differed in important ways, one of which was his emphasis on a hierarchical relationship between the travellers and himself. According 
to Carey, in framing his questions Michaelis 'stresses the superior position of the learned originator of inquiries'. ${ }^{21}$ Carey cites the following remark in Michaelis's Fragen to support his claim:

[The study-bound scholar] with books at his side could gather perhaps ten pieces of data and only be missing the eleventh that he needs to discover the truth. The eleventh piece of data could pass by the traveller's eyes, since he cannot bring a library with him. If the European scholar makes a sufficient effort to provide the traveller with complete and thought-out questions, however, the traveller will be put in a position to accomplish what others could not. ${ }^{22}$

For Carey, 'the traveller is thoroughly subordinated to the task of supplying this superior figure [Michaelis] with detail in which the balance of power in knowledge terms remains undisturbed'. ${ }^{23}$ Yet there is nothing in Michaelis's passage to suggest he saw himself as 'superior' to the traveller. By claiming the traveller needed direction because he could not 'bring a library with him', Michaelis did not mean to suggest the traveller was epistemologically inferior and incapable of producing useful results under any circumstances. Rather, he was arguing that without guidance the traveller was unlikely to produce results useful for the purposes of the expedition, as Michaelis made clear in his critique of previous travellers. ${ }^{24}$

Carey has suggested that Michaelis exhibited his belief in the sedentary scholar's epistemological superiority when he eliminated potential questions for the travellers based on answers provided by his 'company of learned friends' in Göttingen. In so doing, Michaelis 'declare[d] certain things to be "known" and not in need either of further investigation or repetition of observation'.25 Yet Michaelis 'rarely' crossed out questions, 
and he only did so when presented with convincing 'bare facts' (blos Facta), as he considered answers rooted in probability as insufficient. ${ }^{26}$ Michaelis thus assumed certain facts about the field could be known in advance, but this did not necessarily mean such matters required no 'further investigation or repetition of observation'. ${ }^{27}$ Instead, Michaelis eliminated questions to ensure the expedition maximized scientific gains and avoided using time and resources to duplicate knowledge of things already well documented by travellers.

Michaelis's understanding of study-based textual critique and field-based observation as complementary endeavours underscores the problem with seeing the two as radically distinct. This distinction has been emphasised by several historians of science. Outram, for example, has highlighted this divide in her work on the early nineteenthcentury French naturalist George Cuvier and the scholar-traveller Alexander von Humboldt. Cuvier saw field knowledge as 'deeply suspect' and believed 'true knowledge of the order of nature came from the fact of the observer's distance' from the immediacy of experience in the field, while Humboldt saw the explorer's immediate experience as crucial for the production of 'adequate knowledge' about the natural world. ${ }^{28}$ Given Carey's argument about Michaelis's superiority as a study-bound scholar, one might be tempted to think Michaelis, like Cuvier, saw the study as a superior site of knowledge production. Like Cuvier, Michaelis did see the 'immediacy of experience' as problematic, but he saw it as problematic for practical rather than epistemological reasons. For Michaelis, field experience was not problematic because it produced deeply suspect knowledge, but because the traveller's confrontation with the 'tyranny of the immediate' (to borrow 
Outram's phrase) could distract them from observing what was most important for the purposes of a particular expedition.

Similar distinctions between the field and the laboratory have been stressed in Hevly's work on nineteenth-century debates over glacial motion between the alpinist James David Forbes and a Cambridge mathematics tutor named William Hopkins. Forbes saw direct measurement as the surest way to understand glacial motion, whilst Hopkins stressed such motion was best grasped through 'analytical theory' and laboratory work. For Forbes and Hopkins, direct observation and analytical theory were 'two opposing routes to truth'.29 In contrast, the study-bound Michaelis saw direct observation and textual criticism as complementary routes to truth. Neither the study nor the field had an inherently superior epistemological value.

Crucial here is the nature of the questions pursued by Michaelis, and later by Cuvier and Hopkins. Cuvier and Hopkins sought data about the natural world that could be abstracted and generalised. Fundamental for the production of such knowledge were the laboratory, sedentary experimental methods and analytical theory. In contrast, Michaelis wanted travellers to collect accurate and useful knowledge concerning particular histories, geographies, cultures and languages. Empirical conditions in the field and the traveller's bodily experience of such conditions only mattered insofar as they hindered the traveller's ability to collect useful knowledge. Michaelis did try to impose epistemological control on the travellers' experience via instructions, but he did not ask those travellers to impose 'laboratory control on the natural world' as later field scientists began to do, because his concern was not to have the travellers abstract and generalize from their findings. ${ }^{30}$ In short, the idiographic nature of Michaelis's questions meant the field and the study took on 
a different epistemological meaning and function than did the laboratory and the field in the work of later experimental and natural scientists. ${ }^{31}$

Michaelis's case, then, underscores the importance of thinking about how contemporaries themselves understood knowledge production in the study and the field. Contemporaries did recognise a 'distinction between knowledges of the study and the field', between 'cabinet geography' and data collected on long-distance voyages. Yet, as Driver has argued, this distinction 'was far from being a fixed boundary'. ${ }^{32}$ Scholars such as Michaelis sought to bridge the gap between the study and the field through travel instructions and the textual critique of field knowledge. ${ }^{33}$ In so doing, scholars sought to produce more accurate historical and geographical descriptions, rather than to sharpen the epistemological divide between the study and field.

The remainder of the paper outlines the ways that learned authority figured in Büsching and Michaelis's study-bound geographical practice. I understand the study as a meaningful place for knowledge production rather than as a place 'on the margins' of Enlightenment science. ${ }^{34}$ I take seriously the personal relations and values that underlay geographical knowledge production. Doing so allows one to glimpse the epistemological and practical messiness of Enlightenment geography by focussing upon contemporaries' own recognition of that messiness. ${ }^{35}$

\section{WRITING THE EARTH ANEW IN THE STUDY: BÜSCHING'S LEARNED AUTHORITY AND THE MORAL ECONOMY OF GEOGRAPHICAL KNOWLEDGE}

To understand how geography and learned authority figured in Büsching's geography of Asia and Michaelis's expedition, it is important to understand the origins of Büsching's 
Neue Erdbeschreibung project, as well as his friendship with Michaelis. I here suggest Büsching's efforts to establish a new methodological foundation for geography was inseparable from concerns with learned authority and the moral economy of geographical knowledge.

Concerns with learned authority and the geography of knowledge were present from the outset of Büsching's project. His project began when he recognised that geography books based purely on study knowledge were insufficient. Büsching's critique of such books originated in his experience of the world outside the study. More precisely, it originated on a trip he made to St. Petersburg in 1749-1750. Büsching had gone to St. Petersburg because the Danish diplomat Count Lynar, whose son Büsching tutored at the time, had moved there from Köstritz. Büsching's experiences travelling to St. Petersburg and his time in the city itself alerted him to the 'great uselessness' of the descriptions in existing geographies, such as those by Johann Hübner and Johann Georg Hager. ${ }^{36}$ He found such works contained particularly inadequate descriptions of the Russian Empire, and realised that to produce a more useful description of that empire, and the earth more broadly, he needed to begin gathering geographical reports from scholars and government officials. In St. Petersburg he 'made the collection of geographical reports a primary task'. Büsching, then, had decided knowledge gathered in the field, and from scholars elsewhere, would provide a solid foundation for a new earth description and, indeed, for his geographical authority. ${ }^{37}$

Büsching continued to lay the groundwork for his new project, and for this new form of geographical authority, when he returned to the German territories in late 1750 . As he wrote to historian Gerhard Friedrich Müller in February 1751: 'For some time now I 
have been working on a new geographical handbook, and to this end I am bringing together a large mass of the best geographical books and reports'. ${ }^{38}$ Büsching compiled material as he tutored Count Lynar's son in Itzehoe, but only had access to the count's library at the time. In early 1752 , however, he completed a trial version of his new geography, namely his description of the duchies of Schleswig and Holstein. ${ }^{39}$ Several months later he visited his former teacher Eberhard David Hauber in Copenhagen, who suggested Büsching continue work on his Neue Erdbeschreibung at his home in the city and offered to support him financially. Büsching accepted Hauber's offer and left Soröe for Copenhagen in August 1752.40 In Copenhagen he regularly utilised Hauber's large map and book collection and eagerly sought his counsel on geographical matters. Büsching also used the 'large library' of the diplomat Johann Albrecht von Korff, 'which consisted of books from all sciences, and especially historical ones'. ${ }^{41}$ With access to such libraries and ample time Büsching completed the first two volumes of the Neue Erdbeschreibung. At the same time he cultivated ties with Danish scholars and expanded his correspondence network, which further solidified the empirical and social grounds for his geographical authority. ${ }^{42}$ In the Neue Erdbeschreibung Büsching sought to lay a new methodological foundation for geography. His effort to lay this foundation was not just a matter of methodology, however, but also of moral economy. This is evident in Büsching's critique of existing handbooks. As several scholars have noted, Büsching critiqued existing geographies because they lacked rigour, relied on available and well-known secondary sources rather than primary sources, plagiarised material from other books, and failed to judge sources impartially. ${ }^{43}$ Geography handbooks thus contained 'countless errors and omissions', 'much fabulous material', and descriptions of 'the morals and customs of 
foreign peoples' that Büsching found unsuitable for children. For Büsching, such works proved untrustworthy and had 'little use' - a strong critique in a milieu where utility served as a key criterion for judging an author's work. ${ }^{44}$ His critique, moreover, suggests he believed existing geography books were underwritten by a bankrupt moral economy of knowledge, wherein authors implicitly sanctioned shoddy scholarship, plagiarism and partisan descriptions of foreign peoples. Indeed, like other Aufklärer, Büsching believed that how people practiced scholarship reflected their character and the values of wider learned communities. ${ }^{45}$

Büsching's geographical project was founded on a different moral economy of knowledge, one that valued rigour, impartiality and rational Christianity. His commitment to such values underwrote his own claims to learned authority. Those claims rested on obtaining 'the actual and best sources themselves', which included printed books and maps, written reports from 'skilled and officious men from countless places near and far', verbal reports from trusted sources and his own observations. ${ }^{46}$ His claims also rested on his commitment to critically and impartially examining sources, and to listing them carefully for his readers. It was precisely these values and his distrust of existing books that led him to proceed 'as if no introduction to geography had been written before'. ${ }^{47} \mathrm{He}$ saw this as the only responsible way to improve the condition of geographical knowledge and to ensure its religious, educational and political utility. ${ }^{48}$

Whilst Copenhagen served as a crucial starting point for Büsching's project, he eventually left Copenhagen to continue his work in the German territories. Upon returning in May 1754 he took up a post at Halle, where he lectured on geography. In July, however, the curator of the University of Göttingen offered Büsching a position in the faculty of 
philosophy as part of the university's effort to bolster geography. In a move symbolic of Halle's waning power and Göttingen's emergence as the centre of the Aufklärung, Büsching accepted the call and left Halle for Göttingen in August $1754 .{ }^{49}$ In Göttingen he wrote a dissertation in theology, lectured on geography and theology, completed the third volume of the Neue Erdbeschreibung on the German states, and published updated editions of the book's first two volumes. His work on the Neue Erdbeschreibung was aided greatly by the university's agreement to subsidize the postage costs for his correspondence. Indeed, his decision to continue his work in the German territories proved wise. ${ }^{50}$

In Göttingen Büsching made connections with the university's prominent Aufklärer, including Michaelis who had moved from Halle to Göttingen in 1745. By the time Büsching arrived in August 1754, Michaelis had already built a reputation as a first-rate scholar and carved out his own place in Göttingen's learned community. ${ }^{51}$ Büsching and Michaelis's views on theology did much to solidify their friendship and intellectual bond. They disagreed on certain issues and Büsching demonstrated a stronger commitment to living his Protestant faith than Michaelis, yet both Aufklärer rejected dogmatic approaches to biblical criticism and Christianity. Far from fanatic, their theological stances centred on reasoned understanding and religious tolerance. Their moderate stances caused them problems, however. Swedish clerical authorities censored Michaelis's treatise on dogmatics for its supposedly heterodox teachings. ${ }^{52}$ Theology faculty in Göttingen and government officials in Hanover also criticised Büsching's 1756 doctoral dissertation, which evidenced his desire to 'purge theology of scholastic inventions, expressions and propositions, and outline theology according only to the Holy Scriptures'.53 Authorities in Göttingen and Hanover found Büsching's work so problematic they eventually barred him from lecturing 
on theology. Crucially, when the theology faculty sought to revoke Büsching's privileges, Michaelis came to his defence and testified that unlike other theology professors in Göttingen, 'students say of Mr Büsching that he thinks more freely, and seeks truth, which makes a good theologian in our enlightened times (aufgeklärten Zeiten)'. ${ }^{54}$ In such 'enlightened times', Büsching and Michaelis's shared commitment to thinking freely helped cement their friendship and respect for one another.

How, then, did Büsching's Neue Erdbeschreibung project become linked to Michaelis's Danish expedition, and what does their geographical correspondence reveal about the geography of learned authority?

'MY OWN PRECISE INVESTIGATIONS': EPISTOLARY GEOGRAPHY AND THE LIMITS TO

\section{LEARNED AUTHORITY}

Before, during and after the Arabian expedition Michaelis and Büsching practiced 'epistolary geography', or rather geography through epistles. ${ }^{55}$ Their letters concerning the expedition and Büsching's geography of Asia, together with Büsching's framing of his geography, suggest that their claims to geographical authority and recognition of that authority's limits were closely linked, and that concerns with authority shaped their studybased efforts to understand 'the East' and to control action at a distance.

In his expedition proposals and Fragen, Michaelis positioned himself as an authority on matters concerning historical geography. In his 1753 speech to the Royal Academy of Sciences, he argued that 'many questions concerning geography, the ancients, and the natural history of the East ... cannot be answered except by someone who travels through Palestine and Arabia more carefully than has been the case up to now'. ${ }^{56}$ In the case of 
geography, scholars lacked reliable knowledge about the Jordan River area, the Dead Sea, the Red Sea, 'famous mountains in ancient geography' such as Seir and Pharan, and the geography of Arabia. In the case of 'the lands on the east side of the Jordan', geographers had fabricated the locations of biblical cities and of 'the mountains and course of the rivers and brooks [in the region], which should be the eternal guides for the geographer'. ${ }^{57}$ In the case of the Red Sea, ancient Greek authorities provided accounts 'in which fables and truth are so intertwined that they require a critique and explanation, and thus even more geographical knowledge of Arabia'. ${ }^{58}$ Scholars knew little about Arabia's geography, moreover, partly because whilst Arab geographies provided details on the region's historical geography they were 'very incomplete' and failed to provide information on geographical changes over time. ${ }^{59}$ By outlining the state of geographical knowledge about Arabia, the Dead Sea and other places Michaelis was staking a claim to his geographical authority concerning 'the East'.

In making authoritative claims about the historical geography of Asia and the Bible, Michaelis situated himself in a geographical tradition. ${ }^{60}$ His positioning was explicit since he cited ancient authorities such as Strabo and Diodorus Siculus, whose accounts were staples in geography texts by the eighteenth century. ${ }^{61}$ His positioning was implicit because whilst he discussed unresolved questions concerning places that figured in well-known biblical geography texts, he did not explicitly mention such texts. ${ }^{62}$ Geography was, however, just one of the many fields Michaelis saw as tools for understanding biblical philology, and he saw geography as no more important than natural history, for example. His interest in the subject nevertheless reflected its fundamental importance for Enlightenment contemporaries' efforts to understand the world. As such, his interest needs 
to be taken seriously and situated within broader histories of Enlightenment geography. ${ }^{63}$

Michaelis did not see himself as an authority comparable to Büsching or even as a geographer, so when he sought to better understand the geography of 'the East' he consulted Büsching. ${ }^{64}$ Their first exchange during the expedition's organisational phase illustrates Michaelis's trust in Büsching's authority and Büsching's own understanding of it. In 1758 Michaelis consulted Büsching about 'the most complete' geographies of 'Egypt, Syria, and Arabia'.65 In response, Büsching evidenced precisely the authority Michaelis expected, and he noted that the best historical accounts of Egypt, Syria and Arabia were found in the Allgemeine Welthistorie (Universal World History, Halle, 1744-1814). ${ }^{66}$ To underscore his knowledge of the text he listed several travel accounts on which it was based, along with texts that could supplement and improve it. He argued that the accounts in the Allgemeine Welthistorie were better than those in geography books, and in so doing extended the critique of existing handbooks he set out in the Neue Erdbeschreibung. As he phrased it, 'What existing geographical works say about such lands is of little value when viewed in relation to the above accounts [in the Allgemeine Welthistorie], and because existing works are so flawed, it would not be worth the effort to improve them'. As such, Büsching concluded it was necessary to draw together and compile existing reports to produce a new, more accurate geography of Asia. ${ }^{67}$ In so doing he asserted the geographical authority that helped ground Michaelis's trust in him.

Büsching's exchange with Michaelis shows the importance of the methodological rigour that underwrote his authority. This becomes particularly clear in a written exchange concerning the geography of central Asia. In the years prior to the travellers' departure, Michaelis wrote to Büsching to ask about the best charts and reports concerning the lands 
on the Caspian Sea's eastern side. ${ }^{68}$ In response, Büsching confidently recommended Abraham Maas's Nova Maris Caspii as the best available map of the region. ${ }^{69}$ When recommending travel reports Büsching proved more circumspect. Whilst he suggested Michaelis consult the accounts in works by Abulfeda, John Hudson, Adam Olearius, Pietro Della Valle and Engelbert Kämpfer, he hesitated to judge their quality. ${ }^{70}$ 'I cannot say which travel accounts offer the best reports about these lands, since I have not precisely and fundamentally investigated this', wrote Büsching. Several lines later he reiterated his hesitance: 'I do not risk judgment in such cases before I have conducted my own precise investigations, and up to now I have postponed such investigations until the fifth part of my Erdbeschreibung'. ${ }^{71}$ Büsching proved hesitant to judge such sources precisely because his learned authority rested on his 'own precise investigations'. By offering judgments without first conducting such investigations, Büsching would have undermined the moral economy of knowledge that underpinned his geographical project.

Büsching's commitment to his project's integrity helped prevent him from figuring prominently in Michaelis's effort to control the travellers' 'action at a distance' through questions and instructions. As Michaelis composed his questions, Büsching was still working on the third and fourth volumes of his Neue Erdbeschreibung and had yet to begin work on the fifth volume in earnest. Büsching only completed the fourth volume in 1761, the year the travellers left Copenhagen. ${ }^{72}$ That year he left Göttingen to take up a post as second pastor at St. Peter's Lutheran church in St. Petersburg. ${ }^{73}$ His move to St. Petersburg, his new duties and other commitments prevented him from devoting significant time to the fifth volume until several years later. ${ }^{74}$ As such, though Büsching's discussions with Michaelis proved important for Michaelis's own efforts to understand the geography of 'the 
East', Michaelis's Fragen exhibited little discernible trace of his consultations with Büsching, and the latter did not play a significant, measureable role in the organisation of the expedition. ${ }^{75}$

Büsching finally found time to pursue his 'own precise investigations' into Asia's geography once he left St. Petersburg for Altona in 1765. In November 1765, he wrote to Michaelis to inform him of his progress on his geography and to lament the scientific gains forfeited by his failure to begin the work sooner. He told Michaelis that he had 'read everything, investigated, excerpted and combined all the most important material' on the geography of Asia. In so doing he found 'much to answer' Michaelis's Fragen, whilst he also encountered 'thousands of questions' he could not answer. ${ }^{76}$ Büsching admitted he 'wished the expedition had been postponed a few years', because it 'would have produced much more value if everything in printed books on Arabia, Syria, Mesopotamia, Assyria, Chaldea and so on had been compiled beforehand, because then one would have been able to better see what material is still missing'. Because he failed to do this work, and failed to supply the travellers with well-informed geographical questions, and because the travellers had not conducted such research themselves, Büsching feared many questions about Asia's geography would remain unanswered: 'I have almost no hope that these questions can be answered based on the reports that Herr Niebuhr and his deceased colleagues have collected, because such questions will have scarcely crossed their minds.' 77 Because Büsching had not completed his 'own precise investigations' before the travellers left, the expedition forfeited the sort of scientific gains Michaelis hoped to capture through careful planning. 
Büsching's remarks on the expedition's lost utility evidenced his newly acquired knowledge of Asia's geography and his confidence as a recognized geographical authority. Such claims also exhibited Büsching's desire to assert his epistemological superiority over the travellers and to position the study as the privileged locus for geographical knowledge production. In the preface to Büsching's geography of Asia he noted, 'Every line in my book is a question for future travellers, and I especially wish travellers would direct their attention to what I expressly indicate as unknown or as uncertain.'78 The 'superiority' argument is complicated, however, if one reads on in his preface. After suggesting travellers should direction their attention to what he expressly identified as 'unknown or as uncertain', Büsching further added that, 'If travellers cross out and add much to each page [of my geography], then my work has achieved one of my goals for its utility'. ${ }^{79} \mathrm{He}$ thus saw his claims as open to empirical scrutiny rather than as unassailable truth claims. This position was consistent with the initial framing of his project, as he had already invited scholars and travellers to critically engage with his work in the preface to the first volume of his Neue Erdbeschreibung..$^{80}$ By inviting readers to critically scrutinise his claims in the study and the field, Büsching hoped to produce more useful and accurate knowledge of the terraqueous globe.

That Büsching believed his geography of Asia contributed new and useful knowledge, and that he positioned himself as a geographical authority, is clear from the preface to his geography. As he had in the preface to the Staats-Beschreibung and the Neue Erdbeschreibung, Büsching emphasised the moral economy of knowledge that distinguished him from his predecessors. ${ }^{81}$ He repeated his claims about how he could have made things easier for himself by drawing on his predecessors. He also reflected on 
what the increasing availability of travel account collections and universal histories meant for practicing geography. Some commentators believed that published collections of travel accounts made it less difficult 'to describe Asia, Africa and America'. Büsching argued that to rely primarily on such works 'is far from sufficient to the first great task for a true and industrious geographer', who 'requires far more sources' to describe the earth. Moreover, he challenged those who might question the quality of his work, and suggested that if critics took the time to judge it for themselves, they would recognise its high quality and understand the basis for his claims to geographical authority. ${ }^{82}$

Crucially, Büsching recognised that his geographical authority on Asia had limits. He knew his efforts to carefully sort through the mass of accounts on Asia were insufficient to produce 'a proper and complete description' because Europeans simply lacked geographical knowledge about many places and regions in 'the East'. ${ }^{83}$ Asia was, as Withers has noted, on Enlightenment's margins. Büsching underscored this point in 1766 when he remarked to Michaelis that 'To draw up new maps of Asia is impossible, since we do not know the true location of places. Someone could spend their lifetime just creating maps for my geography of Asia'. ${ }^{84} \mathrm{He}$ acknowledged his account remained incomplete because, as his Christian faith taught him, 'all human creations are incomplete and remain so'. 85 Büsching, then, recognised that whilst scholars could collect more data and improve their knowledge of Asia, knowledge of the continent's physical and human landforms could never be entirely mastered given the practical and intrinsic limits to human knowledge.

Recognition of the limits to authority, then, was closely linked with claims to learned authority. Whilst Michaelis made claims to geographical authority, and situated himself in a geographical tradition, he nevertheless recognised that his authority had limits and he 
turned to his friend Büsching for geographical counsel. At the same time, whilst Büsching was keen to assert his authority, his letters to Michaelis show that his authority rested on an earnest commitment to his project's underlying moral economy of knowledge. His commitment prevented him from figuring more visibly in Michaelis's efforts to control the travellers' action at a distance. What, though, does Büsching and Michaelis's engagement with Niebuhr's geographical work in the expedition's wake say about the study-field relationship and the geography of learned authority?

\section{EVALUATING NIEBUHR'S GEOGRAPHY IN THE STUDY}

Analysis of Niebuhr's reports took place in several ways. Büsching integrated Niebuhr's reports into subsequent editions of the geography of Asia, whilst he and Michaelis reviewed Niebuhr's Beschreibung and Reisebeschreibung in learned journals. Their analysis of Niebuhr's reports suggests they believed his work bolstered their claims to produce credible rather than superior knowledge in the study.

In the second edition of his geography of Asia that appeared in 1771, Büsching sought to improve his book and bolster his authority by including unpublished material solicited from Niebuhr. Niebuhr sent him 'all the completed maps and related engravings belonging to his important travel account' and his answers to Michaelis's questions. Niebuhr also commented on the first 311 pages of Büsching's book. He corrected Büsching's remarks on things like the use and pronunciation of Arabic words, city and town locations, the distances between places, the destruction of cities, religious sects, ruling governing officials, cultural groups in particular towns and the presence of robbers. ${ }^{86} \mathrm{In}$ the text itself Büsching drew on Niebuhr's reports, especially in his description of Arabia 
where Niebuhr often served as his only source. ${ }^{87}$ By including Niebuhr's material and specifying what he obtained from the traveller, Büsching sought to underscore his connection to the expedition, to improve his geography of Asia and to bolster his geographical authority. 88

Faithful to the moral economy of knowledge underlying his project, Büsching subjected Niebuhr's reports to critical scrutiny. He compared Niebuhr's claims with those in existing accounts whenever possible, though he could only do so when Niebuhr's reports concerned places Europeans had travelled through or spent time in, such as Egypt. ${ }^{89}$ When it came to areas unfamiliar to Europeans, Büsching faced a dilemma common to scholars and the broader learned public who engaged with travel accounts, namely how to evaluate the credibility of such reports. As Outram has argued, 'The testimony of the explorer was, by itself, no guarantee of anything, when such testimony precisely concerned the distant, the new and the previously unseen'.$^{90}$ Büsching could not base his trust on close personal knowledge of Niebuhr, as there is little evidence to suggest they knew each other well. ${ }^{91} \mathrm{He}$ could only judge Niebuhr's claims based on the methodological care Niebuhr evidenced in his reports and what he knew of Niebuhr's reputation from Michaelis and others. By making such judgments and critically scrutinising Niebuhr's reports, then, Büsching upheld the moral economy of knowledge that underlay his geographical authority and simultaneously sought to bolster that authority.

Concerns with authority and credibility figured in Büsching's reviews of Niebuhr's published work. ${ }^{92}$ His reviews added credibility to Niebuhr's work and bolstered the authority of his own. Büsching described Niebuhr's work as 'very significant for descriptive and illustrative geography'. Niebuhr provided 'a supply of reports, the likes of which no 
recent author of works on Arabia has delivered'. Such remarks were significant, coming not only from one of Europe's leading geographers, but one who had recently published a geography book on Asia. ${ }^{93}$ Büsching augmented his own credibility, moreover, in his critique of Niebuhr's work, by noting the lost utility that resulted from the expedition's failure to harness his geographical authority. Niebuhr's work evidenced this failure in its inclusion of information 'already partly known from books'. Still, Büsching viewed Niebuhr's duplication of observations as useful because such duplications provided 'many confirmations of my own compiled reports'. ${ }^{94}$ One could argue that Büsching's claim marked another effort to assert his superiority as an all-knowing armchair scholar, yet his claim is better read as an effort to render the expedition's organisational failures productive. Niebuhr's confirmations were productive because they lent credibility to Büsching's claims to produce reliable knowledge in the study.

Büsching's critique contained further remarks that could be interpreted as an attempt to demonstrate his epistemological superiority as a study-bound scholar. In particular, one could point to Büsching's claim that his geography of Asia could serve as a corrective to Niebuhr's account. As he observed in his review of Niebuhr's Beschreibung, 'In my [geography of Asia] one finds more than a few places that [Niebuhr] misses, and many more reports on individual regions and places than in his work: I could also note a few places here and there in his work capable and in need of improvement'. ${ }^{95}$ Niebuhr had omitted places because Büsching failed to provide the travellers with a guide containing questions Büsching found important. Niebuhr's work required 'improvement' because Büsching failed to coordinate his project with Michaelis's, rather than because Niebuhr lacked sufficient scholarly acumen or failed as a traveller. Büsching's praise for Niebuhr's 
work, and particularly his claim that Niebuhr represented the ideal traveller, suggests Büsching saw Niebuhr as a capable learned traveller. ${ }^{96}$ Büsching desired to improve Niebuhr's accounts because he wanted to render them more productive, rather than because he wanted to reinforce an epistemological divide between the scholar in the study and the traveller in the field.

Niebuhr's own reflections in his Beschreibung von Arabien further underline the problem with assuming an epistemological divide separated the study and the field in the expedition context. In the preface to his Beschreibung Niebuhr admitted he wished he had had access to Büsching's geography of Asia before he left for Arabia. Büsching's book 'would have been a great aid to me on my journey', remarked Niebuhr, 'because [Büsching] has in his work compiled with great effort everything that is noteworthy that one finds in Arabic and Greek texts known in Europe and in all travel accounts of Arabia'. Likewise, Niebuhr added, Büsching's text would have proved helpful because Büsching had compiled, compared and attempted to reconcile the various names given to places in different languages. ${ }^{97}$ Niebuhr's remarks suggest he viewed the relationship between the studybound scholar and the learned traveller as productive rather than as antagonistic.

In his analysis of Niebuhr's geographical work, Michaelis, like Büsching, showed a desire to integrate knowledge from the field and the study. His reviews evidenced assertions of geographical authority when Michaelis situated Niebuhr's contributions within a longer geographical tradition. In his review of the Reisebeschreibung von Arabien, he praised Niebuhr's map of the Nile Delta for its precision, its grounding in Niebuhr's own observations, and its improvements on older, imprecise and unreliable maps that 'mix up the certain and the uncertain'. He maintained that 'anyone familiar with geography' should 
find Niebuhr's precision and inclusion of Arabic place names in his maps of Egypt 'pleasing'. Michaelis was so impressed with Niebuhr's work he concluded that 'In a single book review I cannot show how much knowledge of Egypt's historical geography has gained' from Niebuhr's efforts. ${ }^{98}$ Michaelis also commended Niebuhr's study-bound geographical work, lauding Niebuhr for comparing his observations against reports in printed works by 'indigenous geographers among the Arabs' such as Scherif Idris. Through his careful work in the field and the study, concluded Michaelis, Niebuhr had produced 'a very important and new geographical description of Arabia'. ${ }^{99}$ By making such claims, Michaelis at once highlighted the expedition's geographical value and demonstrated his own geographical authority.

Michaelis critically engaged with Niebuhr's geographical reports as well and at times challenged their claims. Yet, what he challenged was Niebuhr's conjectures about place names - and specifically the names 'Hud' and 'Mariba' - rather than Niebuhr's eyewitness reports about those places. Michaelis evidenced a more antagonistic tone when he responded to Niebuhr's suggestion that Michaelis would have translated a passage from the book of Moses differently had he first seen Niebuhr's answers to his Fragen. ${ }^{100}$ Yet, in neither case did Michaelis challenge Niebuhr's credibility as an observer in the field. He instead questioned Niebuhr's linguistic skills, which Niebuhr himself admitted were limited. Michaelis acknowledged he sent Niebuhr on the expedition to perform mathematical rather than philological duties, however, and argued Niebuhr accomplished far more outside his assigned field than anyone could have expected. ${ }^{101}$

Like Büsching, Michaelis believed Niebuhr's geographical reports lent credibility to knowledge from the study. If some of Niebuhr's reports duplicated knowledge 'already 
partly known from books', those reports also lent credibility to ancient authors' descriptions of landscapes and place names. For instance, Niebuhr reported that 'a Muslim from India that had been in Yemen a long time' had told him 'Usal was the ancient name of [the city] Sanaa', and Michaelis concluded that this account was 'important, because it coincides with so many ancient reports'. ${ }^{102}$ Similarly, he claimed Niebuhr's account of the mouth of the Nile River as dangerous coincided with ancient descriptions:

The dangerous mouth of the Nile River, already so faithfully and poetically described by Homer, is here described in roughly the same manner - only in a less dangerous time - as in [Robert] Wood's An Essay on the Original Genius and Writings of Homer. I note this primarily to credit Abulfeda, who in his Egyptian Geography - which I published last year - also mentions the mouth of the Nile as very dangerous. ${ }^{103}$

In addition, Michaelis argued that Niebuhr's reports on the fertility of the mountainous regions and steppes of Arabia supported his own description of these regions in his Mosaisches Recht (6 volumes, Frankfurt a.M., 1770-1775).104 Niebuhr's eyewitness reports thus bolstered the credibility and authority of Michaelis's study-bound work on the historical geography of 'the East'. They supported the credibility of the study as a site where, through critical analysis, reliable knowledge could be produced.

Michaelis and Büsching's claims to authority concerning 'the East', and their use of Niebuhr's reports, inevitably raise such questions about how they should be understood in relation to Said's notion of Orientalism. Their work was indeed Eurocentric insofar as they sought data about Arabia that would 'assist in the elucidation of the Old Testament, a document of the European tradition'. ${ }^{105}$ Their work also included established early modern 
tropes about the poor state of Arab scholarship, the less cultivated state of Bedouins compared with sedentary Arabs and Muslims' subservience to ancient customs and history. ${ }^{106}$ To simply assume their work was Orientalist, however, is to ignore the historical context of Said's argument. ${ }^{107}$ Said based his argument on the work of nineteenth- and twentieth-century French, British and American intellectuals, whose work he saw as bound up with modern institutionalized disciplines and colonial endeavours in the Middle East. By contrast, Michaelis and Büsching inhabited an academic world without modern disciplines, and a political world where none of the German territories possessed colonies in the Middle East. To assume Said's historically specific argument can be applied unproblematically to Büsching and Michaelis's case is to ignore the particular geographies of Enlightenment that shaped their Aufklärungsgeographie. ${ }^{108}$

\section{CONCLUSION}

This paper has illustrated the sedentary cultures of exploration at work in the context of the Danish expedition. It has shown that whilst understanding the cultures of exploration that defined travellers' experiences in the field is important, so too is understanding the ways study-bound scholars in Europe sought to direct and make sense of field observations through textual critique in the study. For Michaelis and for Büsching, efforts to direct the Danish expedition members' vision in the field were not motivated by epistemological fears about the unreliability of field knowledge. Rather, they feared that the travellers' immersion in the 'tyranny of the immediate' could direct their focus to unimportant or already known things, and thereby decrease the utility of their observations and indeed the expedition. ${ }^{109}$ To produce the most useful knowledge the travellers' vision needed to be 
guided. This was best done from the study, by scholars familiar with unresolved questions about the history, geography and languages of 'the East'. Whilst practical circumstances at home and in the field ultimately prevented Michaelis and Büsching from guiding the travellers in the way they hoped, they nevertheless productively integrated Niebuhr's reports with the realm of textual critique by framing his work within broader scholarly debates. At the same time, they used Niebuhr's findings to legitimate the credibility of study-bound textual critique. Michaelis and Büsching thus sought to bring textual critique into a productive methodological alliance with observation in the field.

Büsching and Michaelis's case has wider consequences for understanding the making of Enlightenment geography. It illustrates the importance of understanding what Withers has called the making of geography 'in the margins', namely the ways correspondence and manuscripts helped shape geographical knowledge in its final printed form, whether that be instructions to travellers, geographical compendia or periodicals. ${ }^{110}$ Though geographers have done excellent work on geography books and their 'political languages', and on the different ways geography books were used in different places, they have done comparatively little to excavate the practices of epistolary geography and other forms of marginal geography. ${ }^{111}$ Yet, investigating this geography and practices of textual critique is crucial if we want to understand the ways contemporaries navigated matters of authority and credibility. It is also crucial if we want to better understand the ways geographical knowledge travelled - and perhaps, more importantly, failed to travel - from the study into instructions for travellers, and from the study into more conventional print forms. 
In calling for attention to textual critique in the study I am not suggesting that this should be privileged over attention to empirical encounter in the field. Rather, I would argue that it is only through careful attention to the ways the sedentary textual practices were related to empirical encounters in the field that we can better grasp how the study and the field were co-constituted as knowledge production sites. The study, like the laboratory, has 'always exist[ed] in relation to an external realm', which includes not only the field, but also 'financial, material, and cultural resources'.112 Knowing how the study related to such external factors is crucial if we want to better grasp the various ways geographical knowledge was made and used in different places. In short, understanding what I would call the historical constitution of the study is crucial for shedding further light on the geography of Enlightenment geography's making.

In Büsching and Michaelis's case we see a recognition amongst Enlightenment contemporaries that the geography of knowledge mattered. They recognised that bringing together the study and the field was a difficult and messy task precisely because of the study's links to the 'external realm'. Indeed, the success of Michaelis's efforts to contexutalise the Old Testament and Büsching's efforts to describe the geography of Asia depended as much on personal circumstances, learned networks, communication, timing and exigencies in the field as it did on their scholarly rigour and learned authority. The process of revealing Asia's geography to European eyes, then, was never just a matter of Niebuhr and his fellow travellers' exploits. It was also about the ways contemporaries tried to bridge the divide between the study and the field. 
${ }^{1}$ A.F. Büsching to J.D. Michaelis, Berlin, 19 Jan. 1768, Codified Manuscript Michaelis 321, Nachlaß Johann David Michaelis, Niedersächsische Staats- und Univeristätsbibliothek Göttingen (hereafter NStUBG), fol. 216, 'Zu einiger Shadloshaltung schicke ich Ewr. hier 3 neue geographische Bogen zur Fortsetzung der Beschreibung $\underline{\text { Arabiens: }}$ aber zu meiner Unlust ist die gänzliche Besschreibung des Berges $\underline{\underline{\text { Sinai }}}$ und des vorgegebenen $\underline{\underline{\text { Steins}}}$, den Moses geschlagen habe soll, in diesen Bogen nicht enthalten....Wenn der Bogen fertig ist, will ich Ewr. denselben mit der Post übersenden; den der $\underline{\underline{\text { Sinai }}}$ hat mir zu viel Mühe und Zeit gekostet, daher ich meine Abhandlung von denseleben für erheblich, und Dero Beurtheliung werth halte' (all emphasis in original). All translations from the German are my own.

2 See P.H. Reill, The German Enlightenment and the Rise of Historicism, Berkeley, 1975, 44, 82; L.J. Baack, Undying Curiosity: Carsten Niebuhr and The Royal Danish Expedition to Arabia (1761-1767), Stuttgart, 2014, 31-32, 35. On Michaelis, see also M. Legaspi, The Death of Scripture and the Rise of Biblical Studies, Oxford, 2010, here 90; A.-R. Löwenbrück, Johann David Michaelis et les débuts de la critique biblique, in: Y. Belaval, D. Bourel (Eds), Le siècle de Lumières et la Bible, Paris 1986, 113-128; Löwenbrück, Judenfeindschaft im Zeitalter der Aufklärung. Eine Studie zur Vorgeschichte des modernen Antisemitismus am Beispiel des Göttinger Theologen und Orientalisten Johann David Michaelis (1717-1791), Frankfurt a.M., 1995.

${ }^{3}$ See J.D. Michaelis, Abvfeldae tabvla syriae cvm excerpt geographic ex Ibn Ol Wardii Geographia et historia natvrali. Arabice nvnc primvm edidit, Latine vertit, Leipzig, 1766, Cod. Ms. Michaelis 146, NStUBG (this was Michaelis's own copy, which is held in the Göttingen archives); Michaelis (Ed), Abvlfedae Descriptio Aegypti, arabice et latine, ex codice parisiensi edidit, latine vertit, notas adiecit, Göttingen, 1776.

${ }^{4}$ A.F. Büsching, Neue Erdbeschreibung, 5. Th., 1. Abt. [Volume 5, Part 1], welche unterschiedene Länder von Asia begreift, Hamburg, 1768. Büsching referred to the fifth volume as his 'geography of Asia' (Erdbeschreibung 
von Asien) in his letters to Michaelis. See for example Büsching to Michaelis, Altona, 7 Dec. 1765, Cod. Ms. Michaelis 321, fol. 189, NStUBG.

${ }^{5}$ See A. Kühn, Die Neugestaltung der deutschen Geographie im 18. Jahrhundert, Leipzig, 1939, 79. Kühn's claims are repeated in E. Plewe, Studien über D. Anton Friedrich Büsching, in: H. Paschinger (Ed), Geographische Forschungen. Festschrift zum 60. Geburtstag von Hans Hinzl, Innsbrück, 1958, 202-223, at 221; H. Beck, Große Reisende. Entdecker und Erforscher unserer Welt, Munich, 1971, 116.

${ }^{6}$ See J.D. Michaelis, Fragen an eine Gesellschaft gelehrter Männer, die auf Befehl ihro Majestät des Königes von Dännemark nach Arabien reisen, Frankfurt a.M., 1762, Vorrede [Preface], b2r-b2v, b5v-b6v.

${ }^{7}$ I borrow the term 'cultures of exploration' from F. Driver, Geography Militant: Cultures of Exploration and Empire, Oxford, 2001.

${ }^{8}$ See especially L.J. Baack, 'A practical skill that was without equal': Carsten Niebuhr and the navigational astronomy of the Arabian Journey, 1761-7, The Mariner's Mirror 99 (2013) 138-152; Baack, Undying Curiosity, 46-55, 119-135, 297-322, 385-390; also I.W.J. Hopkins, The maps of Carsten Niebuhr: 200 years after, Cartographic Journal 4 (1967) 115-118; D. Henze, Carsten Niebuhrs Bedeutung für die Erdkunde von Arabien, in: C. Niebuhr, Beschreibung von Arabien und die umliegenden Ländern, Graz, 1969 [Copenhagen, 1772], iii-xiii.

${ }^{9}$ This paper marks the first step in a broader effort to write the history of Aufklärungsgeographie and Büsching's pivotal role in it. Aufklärungsgeographie is a neologism in German. I use this term to underscore the fundamentally 'placed' nature of geography and Enlightenment, rather than to suggest Büsching and Michaelis practiced a radically different form of geography from scholars elsewhere. On the 'placed' nature of Enlightenment, see C.W.J. Withers and D.N. Livingstone, Introduction: on geography and enlightenment, in: D.N. Livingstone, C.W.J. Withers (Eds), Geography and Enlightenment, Chicago, 1999, 1-28; C.W.J. Withers, Placing the Enlightenment: Thinking Geographically About the Age of Reason, Chicago, 2007. On the German Aufklärung, see for example H.E. Bödeker and U. Herrmann (Eds), Über den Prozess der Aufklärung in Deutschland im 18. Jahrhundert. Personen, Institutionen und Medien, Göttingen, 1987; F. Kopitzsch, Sozialgeschichte der Aufklärung in Deutschland. Eine Skizze, in: H. Berding, E François, H.-P. Ullmann (Eds), Deutschland und Frankreich im Zeitalter der französischen Revolution, Frankfurt a.M., 1989, 373-390. Scholars have done important work on Enlightenment geography in England, Scotland, France and the early American 
Republic, but said far less about the German case, especially in the Anglophone literature. For a recent review of this literature, see C.W.J. Withers, The Enlightenment and geographies of cosmopolitanism, Scottish Geographical Journal (2012) 1-18. For work on German geography in English, see M. Bowen, Empiricism and Geographical Thought, Cambridge, 1981, 153-161, 206-209 (on Büsching, Göttingen and Kant); D.N. Livingstone, The Geographical Tradition: Episodes in the History of a Contested Enterprise, Oxford, 1992, 108109, 113-117 (on Büsching and Kant); Withers, Placing the Enlightenment, 183-184, 223-224 (on geography in Göttingen); Withers, Kant's geography in comparative perspective, in: S. Elden, E. Mendieta (Eds), Reading Kant's Geography, Albany, NY, 2011, 47-65. In the German literature, see especially Kühn, Neugestaltung. 10 Withers, Placing the Enlightenment, 12. On geography as a discipline, see Withers, Geography in its time: geography and historical geography in Diderot and d'Alembert's Encyclopédie, Journal of Historical Geography 19 (1993) 255-264; R.J. Mayhew, The character of English geography, c. 1660-1800: a textual approach, Journal of Historical Geography 24 (1998) 385-412; Mayhew, Enlightenment Geography: The Political Languages of British Geography, 1650-1850, New York, 2000.

${ }^{11}$ Withers and Livingstone, Introduction: on geography and enlightenment, 4; Withers, Placing the Enlightenment, 5-21.

${ }^{12}$ S. Shapin, A Social History of Truth: Civility and Science in Seventeenth-Century England, Chicago, 1994, 27; see also L. Daston, The moral economy of science, Osiris 10 (1995) 3-24; M. Füssel, Die symbolischen Grenzen der Gelehrtenrepublik. Gelehrter Habitus und moralische Ökonomie des Wissens im 18. Jahrhundert, in: M. Mulsow, F. Rexroth (Eds), Was als wissenschaftlich gelten darf. Praktiken der Grenzziehung in Gelehrtenmilieus der Vormoderne, Frankfurt a.M., 2014, 413-437.

${ }^{13}$ On the moral economy of knowledge and its relation to early modern geography, see C.W.J. Withers, Reporting, mapping, trusting: making geographical knowledge in the late seventeenth century, Isis 90 (1999) 497-521.

${ }^{14}$ In using the phrase 'historical constitution of the study', I draw on Golinski, who has argued that 'The constructivist perspective [in the history of science] clearly opens up for exploration the historical constitution of the laboratory'. J. Golinski, Making Natural Knowledge: Constructivism and the History of Science, $2^{\text {nd }}$ ed., Chicago, 2008, 79, emphasis added. 
15 Michaelis proposed the expedition at a November 1753 gathering of the Göttingen Royal Society of Sciences. The quote is from the Minutes of the Königliche Societät der Wissenschaften zu Göttingen, 10 Nov. 1753 meeting, in Göttingische Anzeige von Gelehrten Sachen 139 (17 Nov. 1753) 1241-1244, quote at 1241. 16 On the expedition's organisation, see Baack, Undying Curiosity, 25-91; see also S.T. Rasmussen (Ed), Den Arabiske Rejse 1761-1767. En dansk ekspedition set i videnskabshistorik perspektiv, Munksgaard, 1997; J. Wiesehöfer, S. Conermann (Eds), Carsten Niebuhr (1733-1815) und seine Zeit, Stuttgart, 2002; I. Friis, M. Harbsmeier, J.B. Simonsen (Eds), Early Scientific Expeditions and Local Encounters: New Perspectives on Carsten Niebuhr and 'The Arabian Journey', Copenhagen, 2013.

${ }^{17}$ L.J. Baack, From biblical philology to scientific achievement and cultural understanding: Carsten Niebuhr, Peter Forsskal and Frederik von Haven and the transformation of the Danish Expedition to Arabia 17611767, in: Friis et al. (Eds), Early Scientific Expeditions, 61-77, quote at 63; Baack, Undying Curiosity, 68-69. The phrase 'two very brief questions' is from Niebuhr, Beschreibung, xvi.

${ }^{18}$ See Baack, Undying Curiosity, 68-69, 203-283.

${ }^{19}$ Niebuhr, Beschreibung; Niebuhr, Reisebeschreibung nach Arabien und umliegenden Ländern, 2 Bde. [2 Volumes], Copenhagen, 1774 and 1778. Niebuhr partially completed a third volume that appeared posthumously as Reisebeschreibung nach Arabien und umliegenden Ländern, eds. J.R. Gloyer and J. Olshausen, Hamburg, 1837. Henze reprinted all three volumes as Niebuhr, Reisebeschreibung nach Arabien und umliegenden Ländern, Graz, 1968. On Niebuhr's efforts to publish the expedition's results, see Baack, Undying Curiosity, 286-295.

${ }^{20}$ Baack, A practical skill, 140.

${ }^{21}$ D. Carey, Arts and sciences of travel, 1574-1762: the Arabian Journey and Michaelis' Fragen in context, in: Friis et al. (Eds), Early Scientific Expeditions, 27-50, quotes at 47, 43.

${ }^{22}$ Michaelis, Fragen, Preface, a5r-a5v, my translation; compare Carey, Arts and sciences, 43.

${ }^{23}$ Carey, Arts and sciences, 43.

${ }^{24}$ For his critique of travellers see Minutes, KSdWG; Michaelis, Fragen, Preface, a2r-a6r. Carey, Arts and sciences, 42-44, mentions Michaelis's critique of past travellers and recognises Michaelis's emphasis on utility, but he sees utility as tied to Michaelis's desire for superiority.

${ }^{25}$ Carey, Arts and sciences, 43-44. 
${ }^{26}$ Michaelis, Fragen, Preface, b5v-b6r, quote at b6r. Carey, Arts and sciences, 44, acknowledges that 'in the absence of an example from Michaelis we cannot tell what kinds of questions he eliminated on this basis'. ${ }^{27}$ Commenting on Niebuhr's reports concerning the outfitting of tents in his review of Niebuhr's Reisebeschreibung, Vol. 1, Michaelis noted, "This is just as Arvieux and Shaw have described the matter, and as I have explained it based on the ancients, yet a new eyewitness is not superfluous'. Michaelis, Orientalische und exegetische Bibliothek 7 (1774) 1-54, 29. For Michaelis's other reviews of the Reisebeschreibung, Vol. 1, see Orientalische und exegetische Bibliothek 7 (1774) 174-178 and 8 (1775) 1-6. For his review of Niebuhr's Beschreibung, see Michaelis, Orientalische und exegetische Bibliothek 4 (1773) 64-127; Göttingische Anzeige von Gelehrten Sachen 1 (6 May 1773) 457-471 and (20 May 1773) 514-518.

${ }^{28}$ D. Outram, On being Perseus: new knowledge, dislocation, and Enlightenment exploration, in: Livingstone, Withers (Eds), Geography and Enlightenment, 281-294, especially 286-287. As Driver, Geography Militant, 1317, has rightly argued, however, Outram overdraws this distinction, since Humboldt saw his work in the field as complementary to his work in the study.

${ }^{29}$ B. Hevly, The heroic science of glacier motion, Osiris 11 (1996) 66-86, quote at 72. On the laboratory and its relation to the field, see also H. Kuklick and R.E. Kohler, Introduction, Osiris 11 (1996) 1-14.

${ }^{30}$ K. Richards, The field, in: in J.A. Agnew, D.N. Livingstone (Eds), The SAGE Handbook of Geographical Knowledge, Los Angeles, 2011, 53-64, quote at 59.

${ }^{31}$ For discussion of the laboratory and sedentary sites of natural knowledge creation, see Golinski, Making Natural Knowledge, 79-102. For broader discussions of the place of knowledge, see A. Ophir, S. Shapin, The place of knowledge: a methodological survey, Science in Context 4 (1991) 3-22; Livingstone, Putting Science in its Place.

32 Driver, Geography Militant, 11-20, quote at 13. The classic example of the cabinet geographer is d'Anville. For an excellent discussion that demonstrates the complexity of d'Anville's armchair practices, see L. Haguet, J.-B. d'Anville as armchair mapmaker: the impact of production contexts on his work, Imago Mundi 63 (2011) 88-105.

${ }^{33}$ On this broader point see Driver, Geography Militant, 13.

${ }^{34}$ On armchair geography as something 'on the margins' of Enlightenment science, see Bowen, Empiricism, 144-173. 
35 On the importance of personal relations, see for example Withers, Reporting, mapping, trusting; Withers, Writing in geography's history: Caledonia, networks of correspondence and geographical knowledge in the late enlightenment, Scottish Geographical Journal 120 (2004) 33-45.

${ }^{36}$ A.F. Büsching, Eigene Lebensgeschichte in vier Stücken, Halle, 1789, 119-177, quote at 173. Johann Hübner's Kurze Fragen aus der neuen und alten Geographie, Leipzig, 1693, served as a geography textbook for many students in the German territories, including Michaelis, who praised one of his childhood tutors for 'bringing me rather far in geography and history, particularly through Hübner's work'. J.D. Michaelis, Lebensbeschreibung bey ihm selbst abgefaßt, Rinteln, 1793, 2-3. Hager's handbook was titled Ausführliche Geographie, 3 The. [3 Volumes], Chemnitz, 1746-1747. On Hübner and Hager, see P. Hoffmann, Anton Friedrich Büsching (1724-1793). Ein Leben im Zeitalter der Aufklärung, Berlin, 2000, 146-147. ${ }^{37}$ Büsching, Lebensgeschichte, 173. The importance of Büsching's trip is also noted in Kühn, Neugestaltung, 64. ${ }^{38}$ Büsching to G.F. Müller, Itzehoe, 3 Feb. 1751, in: P. Hoffmann (Ed), Geographie, Geschichte und Bildungswesen in Russland und Deutschland im 18. Jahrhundert. Briefwechsel Anton Friedrich Büsching Gerhard Friedrich Müller, 1751 bis 1783, Berlin, 1995, 39 (Letter 1). Müller was one of Büsching's most important correspondence partners and his primary contact in St. Petersburg (see P. Hoffmann, Einleitung, in: Hoffmann (Ed), Geographie, Geschichte und Bildungswesen, 9-36). Müller's organisation of the Kamtchatka expeditions likely served as a model for Michaelis's own effort to organise the Danish expedition (see Carey, Arts and sciences, 38-39). On the importance of Müller's travel instructions and work, see G. Bucher, 'Von Beschreibung der Sitten und Gebräuche der Völker'. Die Instruktionen Gerhard Friedrich Müllers und ihre Bedeutung für die Geschichte der Ethnologie und der Geschichtswissenschaft, Stuttgart, 2002; H.F. Vermeulen, Anthropology in colonial contexts. The second Kamchatka expedition (1733-1743) and the Danish-German Arabia expedition (1761-1767), in: J.v. Bremen, A. Shimizu (Eds), Anthropology and Colonialism in Asia and Oceania, Surrey, 1999, 13-39.

39 Büsching, Lebensgeschichte, 196, 198-199.

${ }^{40}$ Büsching, Lebensgeschichte, 210; Büsching to G.F. Müller, Soröe, 30 Aug. 1752, in: Hoffmann (Ed), Geographie, Geschichte und Bildungswesen, 41 (Letter 2). Hauber was a respected Lutheran pastor, polymath and geographer. When Büsching was a teenager, Hauber worked in Büsching's hometown of Göttingen, 
where he offered free instruction to students at his home outside regular school hours because he saw the local school as inadequate. Büsching's time as a pupil in Hauber's home was particularly important, because Hauber's moderate theological views and critical, comparative approach to geography influenced him. Büsching, Lebensgeschichte, 32-40, 42-43, 48-49, 54-56, 62. Büsching, Lebensgeschichte, 40, described Hauber as a 'great scholar, excellent preacher, and tremendous friend of humanity'.

${ }^{41}$ Büsching, Lebensgeschichte, 210-211.

42 Büsching, Lebensgeschichte, 218-219, 226.

43 Plewe, Studien, 205-206; Bowen, Empiricism, 155-156; also Büsching, Neue Erdbeschreibung, 1. Th. [Volume 1], welcher Dänemark, Norwegen, Schweden, das ganze rußische Kaisertum, Preussen, Polen, Hungarn und die europäische Türkey, mit denen dazu gehörigen und einverleibten Ländern, enthält, Hamburg, 1754, 2-3. ${ }^{44}$ On utility and Enlightenment geography, see C.W.J. Withers, Encyclopaedism, modernism and the classification of geographical knowledge, Transactions of the Institute of British Geographers 21 (1996) 275298; Mayhew, Character of English geography, 394-395, 406.

45 On this general point, see M. Füssel, 'The charlatanry of the learned': on the moral economy of the Republic of Letters in eighteenth-century Germany, Cultural and Social History (2006) 287-300; Füssel, Die symbolischen Grenzen.

${ }^{46}$ Büsching, Staats-Beschreibung, 7; also Büsching, Erdbeschreibung, Vol. 1, 2-3, 5-6; Büsching, Lebensgeschichte, 219, 226.

${ }^{47}$ Büsching, Staats-Beschreibung, 7-8. For a similar remark, see Büsching, Erdbeschreibung, Vol. 1, 2. 48 Büsching, Erdbeschreibung, Vol. 1, 4.

${ }^{49}$ Büsching, Lebensgeschichte, 232-246; Büsching to G.F. Müller, Copenhagen, 18 Apr. 1754, in: Hoffmann (Ed.), Geographie, Geschichte und Bildungswesen, 50 (Letter 6). To bolster geography in Göttingen, the university also recruited Tobias Mayer, Georg Lowitz, and Johann Michael Franz. See Geheimer Rath an Seiner Königlichen Majestät, Pro memoria, Hannover, 20 Nov. 1750, Kuratorium 5747, Philosphisches Facultät, Tobias Mayer, fol. 2, Universitätsarchiv, NStUB; Geheimer Rath an Büsching, Pro memoria, Hannover, 6 Jul. 1754, Kur. 5751, Phil. Fac., A.F. Büsching, fol. 2-3, Universitätsarchiv, NStUBG; Georg der Andere an den Geheimen Räthe zu Hannover, Pro memoria, London, Kur. 5756, Phil. Fac., G.M. Lowitz, fol. 73-74, Universitätsarchiv, NStUBG. 
${ }^{50}$ Büsching, Lebensgeschichte, 275-278, 308-323; Hoffmann, Büsching, 49-66.

${ }^{51}$ Michaelis had lectured at Halle for three years prior to being called to Göttingen. See Michaelis, Lebensbeschreibung, 40-41; Georg der Andere an der Universität zu Göttingen, Hannover, 16 Jun. 1746, Kur. 5741, Phil. Fac., J.D. Michaelis, Bl. 2, Universitätsarchiv, NStUBG. On Michaelis's reputation, see U. Hübner, Johann David Michaelis und die Arabien-Expedition 1761-1767, in: Wiesehöfer, Conermann (Eds), Carsten Niebuhr, 363-402, 370-371.

52 Hübner, Michaelis, 373-376; Hoffmann, Büsching, 223-242, especially 229; Michaelis, Lebensbeschreibung, 61, 63-64 (on the Swedish case).

53 Büsching, Lebensgeschichte, 289. Hoffmann also highlights this quote in Büsching, 231.

${ }^{54}$ Büsching, Lebensgeschichte, 286-308; Geheimer Rath an Büsching, Pro memoria, 13 Sept. 1759, fol. 21-22, and 20 Sept. 1759, fol. 24-27, Kur. 5751, Phil. Fac., A.F. Büsching, Universitätsarchiv, NStUBG; Hoffmann, Büsching, 53-56, 229, 232. For Michaelis's remark see Büsching, Lebensgeschichte, 265. Michaelis was comparing Büsching to Christian Wilhelm Franz Walch, a member of the theology faculty.

${ }^{55}$ For Withers, the Republic of Letters was a matter of 'epistolary geography' since '[c]orrespondence has to do with movement over space'. Withers, Writing in geography's history, 35-36, 41, quote at 35.

56 Minutes, KSdWG, 1241.

${ }^{57}$ Minutes, KSdWG, 1243; and Michaelis, Fragen, 188 (Question 65), where he argued the locations of 'famous mountains in ancient geography', such as Seir and Pharan were 'typically fixed on maps according more to arbitrariness than to historical reports, never mind measurements'.

58 Michaelis to J.H.E. von Bernstorff, Göttingen, 30 Aug. 1756, Cod. Ms. Michaelis 320, fol. 215, NStUBG, 'in der Fabeln und Wahrheiten so gemischt sind, daß sie eine Critik und Erläutertung braucht, wozu mehr geographische Kenntniß von Arabien nöthig ist'.

${ }^{59}$ Michaelis to Bernstorff, Göttingen, 30 Aug. 1756, Cod. Ms. Michaelis 320, fol. 214-215, NStUBG, 'sehr unzulänglich' (fol. 215). Baack, Undying Curiosity, 28, has also noted Michaelis's critique of Greek and Arabic geographies.

${ }^{60}$ On the geographical tradition, see Livingstone, Geographical Tradition, 1-31. On geography as a textual tradition, see Mayhew, Enlightenment Geography; Withers, Placing the Enlightenment, 178-187. 
${ }^{61}$ Ancient texts that contained reports on Asia were important for early modern scholars given the relative paucity of contemporary reports. See C.W.J. Withers, On Enlightenment's margins: geography, imperialism and mapping in Central Asia, c. 1798-c. 1838, Journal of Historical Geography 39 (2013) 3-18; A. Katzer, Araber in deutschen Augen. Das Araberbild der Deutschen vom 16. bis zum 19. Jahrhundert, Paderborn, 2008, 258-267. On classical authors, see Mayhew, Character of English geography, 397, 399-401.

62 E. Wells, An Historical Geography of the Old Testament, 3 Volumes, London 1711, Vol. 1, 279, 300-302 (Dead Sea), 355-356 (Red Sea), Vol. 2, 88, 86-90 (Red Sea), 126-127, 129, 140-142, 144-145, 148, 271 (Mount Seir); also see J.J. Schmidt, Biblischer Geographus, Züllichau, 1740, 152-155 (Dead Sea), 580, 599 (Red Sea). Whilst I have not found any references to Wells in Michaelis's work, Michaelis probably knew of Wells given his strong connections with English universities and scholars. See Michaelis, Lebensbeschreibung, 27-37; Legaspi, The Death of Scripture, 115-121.

${ }^{63}$ On geography's importance, see Withers, Placing the Enlightenment; Withers and Livingstone, Introduction: on geography and enlightenment.

${ }^{64}$ Few Enlightenment contemporaries referred to themselves as geographers. Mayhew, Character of English geography, 402; Withers, Placing the Enlightenment, 194.

65 Michaelis to Büsching, n.p. [Göttingen], n.d. [1758], Codified Manuscript Philosophie 182: J.D. Michaelis, NStUBG.

66 Büsching to Michaelis, Göttingen, n.d., Cod. Ms. Michaelis 321, fol. 169r, NStUBG; see S.J. Baumgarten (Ed), Die Allgemeine Welthistorie, die in England durch eine Gesellschaft von Gelehrten ausgerfertiget worden. Mit Vorreden und häufigen Anmerkungen, 16 Bde. [16 Volumes], Halle, 1744-1756. Johann Salomo Semler edited the Allgemeine Welthistorie after Baumgarten's death (Vols. 18-30, Halle, 1759-1766). For a history of this work, see M. Conrad, Geschichte(n) und Geschäfte. Die Publikation der "Allgeminen Welthistorie" im Verlag Gebauer in Halle (1744-1814), Wiesbaden, 2010.

${ }^{67}$ Büsching to Michaelis, Göttingen, n.d., Cod. Ms. Michaelis 321, fol. 169r, NStUBG, 'Was die bekanten Geographie um diesen Ländern haben, ist in Ansehung obigen Abhandlungen für nichts zu rechnen, und wegen denselben würde es nicht der Mühe Werth seyn, sie zu verbessern.'

${ }^{68}$ Büsching responded to many letters from Michaelis that have not survived, and thus the content of Michaelis's questions must be inferred from Büsching's responses. 
${ }^{69}$ Büsching to Michaelis, n.p., n.d. [prior to 1761], Cod. Ms. Michaelis 321, fol. 165, NStUBG, 'Die hommanische Charte...gezeichnet von Masio, ist die beste welche wir von denen an der Ostseits des caspischen Sees belegenen Ländern haben.' The map referred to was Abraham Maas, Nova Maris Caspii, et Regionis Usbeck cum Provincijis adjacentibus vera Delineatio in qua itinera Regia et alia notabiliora accurate denotantur, Nürnberg, 1735. Mass's map depicts 'Usbek' directly on the Caspian Sea's eastern side, whilst it depicts the northeast of Persia on the Caspian Sea's southeastern side.

${ }^{70}$ On these travel accounts, see J. Osterhammel, Die Entzauberung Asiens. Europa und die asiatischen Reiche im 18. Jahrhundert, München, 1998, 30, 99, 143, 166, 177, 191, 196, 198, 203; Katzer, Araber, 121-339.

${ }^{71}$ Büsching to Michaelis, n.p., n.d., Cod. Ms. Michaelis 321, fol. 165r, NStUBG, 'Ich kann nicht sagen, welche Reisebeschreibungen die beste Nachrichten von diesen Ländern liefere, den ich habe es auch nicht genau und gründlich untersucht....Ich wage es nicht in solche Fällen zu urtheilen, bevor ich bisher bis wohl den 5te Theil meiner Erdbeschreibung verschoben.'

72 Büsching, Neue Erdbeschreibung, 4. Th. [Volume 4], welcher die vereinigten Niederlande, Helvetien, Schlesien und Glatz enthält, Hamburg, 1761.

${ }^{73}$ Büsching also served as director of the school affiliated with St. Peter's church. Büsching, Lebensgeschichte, 330-502; Hoffmann, Büsching, 67-94.

${ }^{74}$ See Büsching, Erdbeschreibung, Vol. 5, Vorrede [Preface], 2r-3r; Büsching had published an excerpt from the fifth volume two years earlier as Beschreibung des Todten Meeres in Palästina, Hamburg, 1766.

75 Michaelis does not mention Büsching in his Fragen. He does mention Kämpfer's work, which Büsching recommended. Michaelis, Fragen, Instruction §39; also see Fragen, 44 (Question 25), 118, 122 (Question 38), 215-216 (Question 78).

${ }^{76}$ Büsching to Michaelis, Altona, 13 Nov. 1765, Cod. Ms. Michaelis 321, NStUBG, 'Da ich alles gelesen, untersucht, und das Wichtigste ausgezogen habe...' (fol. 186), 'In dem, was ich von Asien schon ausgearbeitet habe, ist manches zur Bereicherung die Fragen, welche Ew. haben drücken laßen, zu finden' (fol. 185v). Büsching repeated his claim about finding answers to Michaelis's Fragen in the preface to his Erdbeschreibung, Vol. 5, Preface, 4r.

77 Büsching to Michaelis, Altona, 13 Nov. 1765, Cod. Ms. Michaelis 321, fol. 186, NStUBG, 'Sie würden eine viel größer Nutzen geschafft haben, wenn vorher alles, was in schon gedruckten Büchern von $\underline{\underline{\text { Arabien }}} \underline{\underline{\text { Syrien, }}}$ 


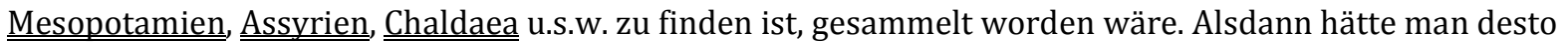
besser sehen können, woran es noch fehle'; 'Ich habe fast gar keine Hoffnung, daß sie aus den Nachrichten, welche Hr. Niebuhr und seine verstorbenen Gefährten gesammelt haben, werden beantwortet werden können; denn sie werden ihnen schwerlich eingefallen seyn'.

${ }^{78}$ Büsching, Erdbeschreibung Vol. 5, Preface, 4r-v.

${ }^{79}$ Büsching, Erdbeschreibung, Vol. 5, Preface, 4r-v, quote at 4r.

${ }^{80}$ Büsching, Erdbeschreibung, Vol. 5, Preface, 4.

${ }^{81}$ Büsching, Erdbeschreibung, Vol. 5, Preface, 3r, 'I know full well that I could make it very easy for myself if I wanted to follow the example of those who have written geographies up to now. In so doing, however, I would not have satisfied my readers' disposition or my own'. Also see Büsching, Staats-Beschreibung, 7. 82 Büsching, Erdbeschreibung, Vol. 5, Preface, 3r-v, quotes at 3r.

${ }^{83}$ Büsching, Erdbeschreibung, Vol. 5, Preface, 3v.

${ }^{84}$ Büsching to Michaelis, Altona, 14 Mar. 1766, Cod. Ms. Michaelis 321, fol. 198v, 'Neue Charten von Asien stechen zu laßen, ist unmöglich, den man weiß die wahre Lage der Orter nicht anzugeben. Es könnte jemand seine ganze Lebezeit damit zubringen, um blos zu meiner Erbeschreibung von Asia Charten zu verfertigen' (emphasis in original).

85 Büsching, Erdbeschreibung, Vol. 5, Preface, 3v.

${ }^{86}$ Büsching, Neue Erdbeschreibung, 5. Th., 1. Abt. [Volume 5, Part 1], welche unterschiedene Länder von Asia begreift, 2. Aufl. [2 ${ }^{\text {nd }}$ edition], Hamburg, 1771, Neue Vorrede [New Preface], 8r-v; for Niebuhr's comments, see Erdbeschreibung, Vol. 5, 622-627 (Appendix).

87 See for example Büsching, Erdbeschreibung, Vol. 5, $2^{\text {nd }}$ ed., 556, 450, 465, 500, 511-512, 511-512, 515-516, 544-545, 549-550, 570, 586, 588, 590, 600-601, 605, 616-617; see also Büsching, Neue Erdbeschreibung, 5. Th., 1. Abt. [Volume 5, Part 1], welche unterschiedene Länder von Asia begreift, 3. Aufl. [3 ${ }^{\text {rd }}$ edition], Hamburg, $1781,512-718$.

${ }^{88}$ An anonymous reviewer of Niebuhr's Beschreibung von Arabien argued that Büsching had taken all the material that was 'useful for geography' from Niebuhr's then forthcoming Reisebeschreibung von Arabien and included it in the second edition of his geography of Asia. Niebuhr responded to the reviewer thusly: 'If one investigates this, however, they will find that this material [that Büsching incorporated in his geography of 
Asia] only includes a few of the reports on the provinces of Yemen and Hedsja that I communicated via letter to the aforementioned learned author [Büsching], as he has also noted in his new preface.' See Niebuhr, Reisebeschreibung, Vol. 1, xv.

${ }^{89}$ He compared Niebuhr's reports against those from Pococke, Shaw, Abulfeda and others, and noted whether Niebuhr had gathered his information from observations or the testimony of local residents. Büsching, Erdbeschreibung, Vol. 5, 2nd ed., 511-512, 516, 549-550, 570, 586, 588, 600, 616 (comparisons of Niebuhr with other sources), 515, 544-545, 550, 590, 601, 605, 617 (on Niebuhr's sources). Also see Katzer, Araber, 278280, 287, 324-327, who discusses sources and tropes Büsching drew on. 90 Outram, On being Perseus, 282-283. On questions of travel, trust and credibility, see also Shapin, Social History of Truth, 243-266; Withers, Reporting, mapping, trusting; I.M. Keighren and C.W.J. Withers, Questions of inscription and epistemology in British travelers' accounts of early nineteenth-century South America, Annals of the Association of American Geographers 101 (2011) 1331-1346.

${ }^{91}$ Büsching's time in Göttingen overlapped with Niebuhr's, and though he does not discuss meeting Niebuhr, he probably did, especially since Niebuhr trained with his colleagues Mayer and Kästner.

${ }^{92}$ Niebuhr's Beschreibung von Arabien was the first work Büsching reviewed in the inaugural January 1773 issue of his Wöchentliche Nachrichten von neuen Landcharten, geographischen, statistischen und historischen Büchern. For his reviews of the Beschreibung, see Wöchentliche Nachrichten 1 (1773) 1-4, 49-54, 149-151. On Niebuhr's Reisebeschreibung, Vol. 1, see Wöchentliche Nachrichten 2 (1774) 112, 116-118, 124-126; Wöchentliche Nachrichten 3 (1775) 115-118. On the Reisebeschriebung, Vol. 2, see Wöchentliche Nachrichten 6 (1778) 19-23, 27-32, 111-112, 117-118, 121-124, 158-160.

${ }^{93}$ Wöchentliche Nachrichten 3 (10 Apr. 1775) 118.

${ }^{94}$ Wöchentliche Nachrichten 1 (4 Jan. 1773) 4; also Wöchentiche Nachrichten 1 (15 Jan. 1773) 50.

${ }_{95}$ Wöchentliche Nachrichten 1 (4 Jan. 1773) 4.

${ }^{96}$ Wöchentliche Nachrichten 3 (10 Apr. 1775) 115-116.

${ }^{97}$ Niebuhr, Beschreibung, xx; also Katzer, Araber, 278.

${ }_{98}$ Orientalische und exegetische Bibliothek 7 (1774) 9-10; see also Orientalische und exeg.etische Bibliothek 4 (1773) 115. 
${ }_{99}$ Orientalische und exegetische Bibliothek 4 (1773) 115. Michaelis similarly argued that 'Niebuhr treated the ebb and flow of the Arabian Gulf precisely and extensively'. Orientalische und exegetische Bibliothek 4 (1773) 126.

100 Orientalische und exegetische Bibliothek 4 (1773) 120-121 (on the translated passage and place names). ${ }^{101}$ Orientalische und exegetische Bibliothek 4 (1773) 116; Michaelis, Lebensbeschreibung, 74-75. 102 Orientalische und exegetische Bibliothek 4 (1773) 118. ${ }^{103}$ Orientalische und exegetische Bibliothek 7 (1774) 5-6. On Michaelis's relation to Wood, see Legaspi, The Death of Scripture, 120-121. 104 Orientalische und exegetische Bibliothek 4 (1773) 82; for other examples of confirmation that concern religious conversion, the blood feud and other topics, see Orientalische und exegetische Bibliothek 4 (1773) 85, 87, 91-94; Orientalische und exegetische Bibliothek 7 (1774) 176.

${ }^{105}$ Baack, Undying Curiosity, 395. Baack refers only to Michaelis, but his claim holds true for Büsching as well. 106 On tropes in early modern writings on Arabs, see Katzer, Araber, 121-339. For Michaelis's remarks on Arabs and science, see Michaelis, Fragen, 6, 8 (Question 2), 46 (Question 24); Göttingische Anzeigen von gelehrten Sachen (6 May 1773) 467-468; Michaelis, Mosaisches Recht, Volume 1, Frankfurt a.M., 1770-1771, 14-15. For Büsching's remarks on Arabs, see for example Büsching, Erdbeschreibung, Vol. 5, 417-424, 435. ${ }^{107}$ Compare J. Hess, Johann David Michaelis and the colonial imaginary: Orientalism and the emergence of racial antisemitism in eighteenth-century Germany, Jewish Social Studies 6 (2000) 56-101, especially 75-82; and Hess, Carsten Niebuhr, Johann David Michaelis, and the politics of Orientalist scholarship in late eighteenth-century Germany, in: Friis et al. (Eds), Early Scientific Expeditions, 75-84. Crucially, see also Baack, Undying Curiosity, 369-377, who rightly critiques Hess's postcolonial reading of the Danish expedition's aims and its place in the history of European colonialism.

${ }^{108}$ Said had little interest in 'German Orientalism'. He suggested 'one of the important impulses toward the study of the Orient in the eighteenth century was the revolution in Biblical studies stimulated by such variously interesting pioneers as Bishop Lowth, Eichhorn, Herder and Michaelis', but had little desire to study how the work of Michaelis, Herder and others functioned in the Aufklärung, or to show how their work led to German Orientalism as an institutionalized discourse. See E.W. Said, Orientalism, New York, 1979, 17-20, 
quote at 17. On Said's relation to German Orientalism, see J. Jenkins, German Orientalism: introduction, Comparative Studies of South Asia, Africa and the Middle East 24 (2004) 97-100.

${ }^{109}$ Outram, On being Perseus, 286.

110 Withers, Writing in geography's history.

${ }^{111}$ See for example Mayhew, Character of English geography; Mayhew, Enlightenment Geography; Mayhew, Geography books and the character of Georgian politics, in: M. Ogborn, C.W.J. Withers (Eds), Georgian Geographies: Essays on Space, Place and Landscape in the Eighteenth Century, Manchester, 2004, 192-211; Withers, Placing the Enlightenment, 167-192; M. Brückner, The Geographic Revolution in Early America: Maps, Literacy, and National Identity, Chapel Hill, NC, 2006.

112 Golinski, Making Natural Knowledge, 91. 